\title{
VERNACULAR LANGUAGE WITHIN THE TRADITIONAL BELL TOWERS: BETWEEN STAIRS, LANDINGS AND FLOORS
}

\author{
A. Mondello ${ }^{1, *}$, A. Salemi ${ }^{1}$ \\ ${ }^{1}$ Department of Civil Engineering and Architecture, University of Catania, via Santa Sofia 64, 95123, Catania, Italy - \\ (attilio.mondello, angelo.salemi)@darc.unict.it
}

\author{
Commission II - WG II/8
}

KEY WORDS: Traditional bell towers, Traditional building techniques, Seismic vulnerability, Conservation, Eastern Sicily.

\begin{abstract}
:
The monumental heritage of European historic centres is characterised by special building types that have drawn, more than others, on the vernacular language of the local traditional architecture. The traditional bell towers, even if built by a specific (but not always known) designer, often have some building elements transliterated from the construction tradition of poor and rural buildings. This language can be found in many examples from different historical periods and in faraway areas, such as Italy and Spain. The external monumentality may not correspond to a complex spatial articulation inside the towers. Instead, it is usual to find belfries in which the vertical connections and any horizontal structures are solved by wooden stairs and floors to reach the bell cell. The used materials and building techniques reveal the design simplicity but also the evidence of a lost "know-how". Due to the nature of the materials, possible damages and lack of maintenance, many of these structures have undergone restoration or transformation works, also whit their replacement for the benefit of most modern construction systems. The research aims to underline the central importance of preventive knowledge of these traditional structures and illustrate some significant cases in Eastern Sicily, a high seismic risk area. These case studies are emblematic for the evidence of several original structures or the extreme effects of the 20th-century interventions. These last works have often compromised the historical and documentary trait of the wooden structures, introducing new vulnerabilities due to the excessive stiffening of the masonry.
\end{abstract}

\section{INTRODUCTION}

In European historic centres, the masonry bell towers have a strong symbolic value for the urban landscape and the history of the local community. The history of their construction often hides a specific design by an architect or an unknown foreman. Despite this, the recognizable external monumentality corresponds to an inner system of floors and vertical connections that borrow their technical solutions from the local architectural lexicon. These building elements, which are simple in terms of materials and technology used, are often little investigated and analysed. In structural restoration works, they are considered a "material of sacrifice" to be replaced in favour of more modern technological solutions.

Instead, it is important to recognize the real dignity to these structures, which represent the cultural evidence of the ancient local workers' ability, that is to be protected and therefore to be preserve.

\section{STATE OF THE ART}

The inner architectural layout of the historic bell towers generally responds to specific needs related to the reaching of the top bell cell and the location of the mechanical clock.

This spatial subdivision was theorized for the first time in 1577 by C. Borromeo (immediately after the Council of Trent) with the necessary indications for the construction of the new ecclesiastical buildings (Della Torre et al., 2000). More specifically, in addition to the indications about the location and the geometric shape of the plan, these "Instructions" indicate how the towers must have a vaulted system both for the ground floor covering and for the floor of the bell cell; the towers must be crowned by a pyramidal or conical summit cusp. Besides, at the intermediate levels, there must be light floors with wooden beams ("assicelle") and "comfortable and safe" stairs, in wood or stone. In this way, if on the one hand, the role of the architect represents the reference point for the geometric configuration of the bell tower, on the other hand, the internal design choices aim at simple solutions with building techniques linked to the world of vernacular architecture.

At the international context, some Spanish studies have conducted a careful analysis of the geometries and the use of the different levels inside the Gothic bell towers in Castilla y León. This inner functional layout is also recurrent in subsequent exemplars in other European historical centres. In these buildings, the vaulted ground floor could serve as a patrician chapel or vestibule of the nave, while the upper floor was used for the choir if facing the nave. The upper levels of the tower, especially if not lit by the windows, were made with wooden floors and were used like the "hidden room" (or "camera oculta"), i.e. a space that housed the hanging weights of the mechanical clock installed in the attic of the bell tower (Sánchez Rivera et al., 2014).

Moreover, the most recent researches about recurring building techniques in historic bell towers also include a study of eighteenth-century bell towers in the Alicante seismic risk area. These towers were made of pressed brick masonry with wooden beamed ceilings and reed mats. (García González, 2015).

\footnotetext{
* Corresponding author
} 
In Italy, a renewed interest in the careful study of the technical construction aspects of traditional bell towers has been shown by empirical studies on the mechanisms of damage in the ruins of churches affected by the 1976 Friuli earthquake (Doglioni et al. 1994). These researches have opened the way to other similar analyses on the bell towers of Venice (Lionello, 2013) and on those in other Italian territories subject to seismic risk (Blasi, 2013; Dezzi Bardeschi et al., 2017).

Reading the few studies listed here can undoubtedly confirm the influence of the vernacular language of basic building (residential and rural) on some design solutions also adopted inside the bell towers. Also considering the specialist literature on traditional building techniques in Sicily (Aymerich, et al., 2007) and, specifically, in the Etna area, the historic bell towers of the latter territory are no exception (Randazzo, 1988; Barbera, 1998; Salemi, 2018). These Etnean specimens are all made of lava stone masonry with lime mortar and volcanic aggregates; the oldest date back to the 13th and 16th centuries, while the most recent ones are the result of reconstruction following the catastrophic earthquake of 1693.

\section{METHODOLOGY}

The research presented here is part of a wider study on the analysis of the geometrical and technical and constructive configurations of traditional bell towers in the Etna area, an area with a high seismic risk. This area consists of the territory of Catania municipality and 42 other Sicilian municipalities on the slopes of the Mount Etna (like the towns of Acireale, near the Ionian coast, Pedara, in the eastern foothills, and Bronte on the north-western side of the volcano).

Starting from a census over the entire area, from direct surveys and the consultation of the databases of the Italian Episcopal Conference $(\mathrm{BeWeb})$ and the Italian Central Institute for Restoration (Risk Map of Cultural Heritage), the research conducted typological classification about 150 specimens, collected a repertoire of recurrent construction techniques and focused some emblematic cases for the area. In this way, the study has empirically identified which of the typological, geometrical and technical-constructive aspects can be considered as real intrinsic vulnerabilities for the survival of these belfries in seismic regions (Mondello 2019; Mondello et al., 2019).

Based on this background, among the traditional building techniques used in traditional Etnean bell towers, the paper identifies the elements that have certainly been borrowed from the vernacular lexicon. So, this highlights their testimonial value and also documents their replacement with more modern building systems, which, however, may induce new vulnerabilities.

\section{FLOORS, STAIRS AND LANDINGS IN THE TRADITIONAL ETNEAN BELL TOWERS}

\subsection{Wooden-beam floors}

The census of traditional bell towers in the Etna area has shown that out of more than 150 examples, only a few of them still retain design solutions typical of local vernacular architecture. As already mentioned, contrary to the monumental appearance of the external walls, the floors of these bell towers were made with materials easily available in the area, in a way borrowed from the vernacular residential buildings with two elevations and wooden beamed ceilings ("solari"). These intermediate floors were made of load-bearing beams in chestnut wood, placed in parallel with the shortest side of the tower plan. According to the economic availability of the customer and the skill of the workers, these beams were more or less worked to obtain a circular or rectangular cross-section. They had the ends inserted in the perimeter walls in specific holes, filled with stone flakes to make the joint. On the beams, there was fir wood planking, without a top finish. The number of beams was a function of their cross-section and the span. The boards were joined together without interlocking and were orthogonal to the beams.

In the Etnean area, this building system was used until the first half of the nineteenth century. In some late nineteenth-century tariff schedules, such as the one drawn up in Catania by the architect F. Fichera in 1893 (Fichera, 1893), different depths are also specified for the beam interlocking in the lava stone masonry, according to the height of the section of the beam (Randazzo, 1988). In the Etnean bell towers, the survival of such wooden structures is more frequent at the top level, below the roof cusp. As already mentioned for the sixteenth century cases in Spain (Sánchez Rivera et al., 2014), this space was frequently used to accommodate the clock machine.

Examples of this type are in the bell towers of the eighteenthcentury churches of Sant'Agata al Borgo in Catania (Figure 1) and in Sant'Antonio Abate in Pedara (Figure 2), where beams and planking have been replaced during restoration works but reproposing the original building techniques. In this case, according to common practice in minor residential architecture, there is a beam with a larger section under the floor supporting the main beams of the floor; this beam was probably added as support for some beams considered to be damaged (De Felice et al., 2006).

Other examples of very light floors, with small beams (with cross-section of a diameter of $8 \mathrm{~cm}$ ) can be found above the bell cell of the church of Santa Maria di Monserrato in Catania (Eighteenth century), now without planking (Figure 3), or in that of the church of San Giovanni in Bronte (Figure 4), dating back to 1614
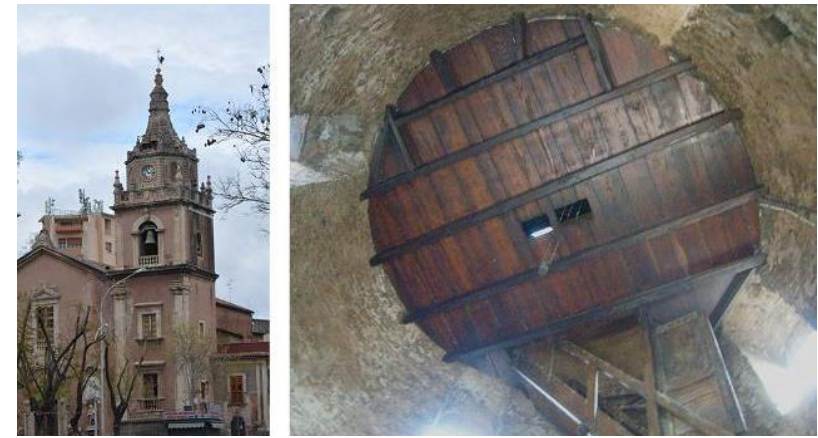

Figure 1. The bell tower of Sant'Agata al Borgo in Catania. On the right, the floor under the cusp.
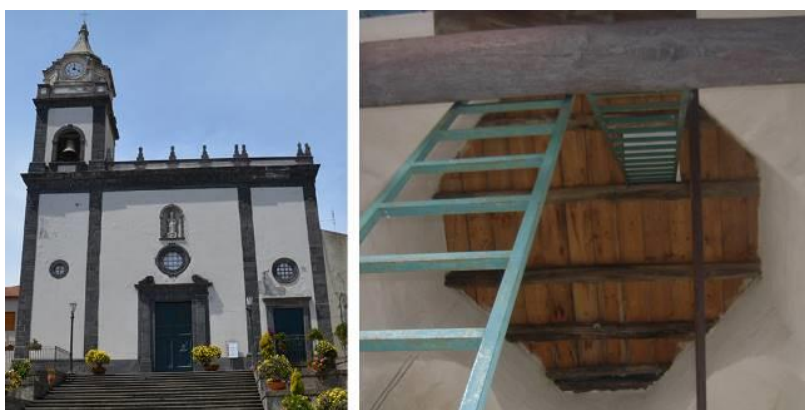

Figure 2. The bell tower of Sant'Antonio Abate in Pedara (Ct). On the right, the floor under the cusp. 

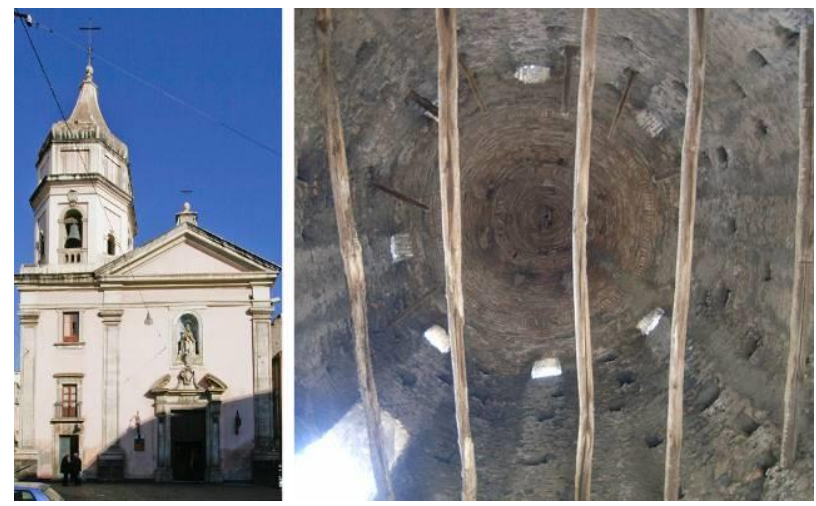

Figure 3. The bell tower of Santa Maria di Monserrato in Catania. On the right, original beams of the floor under the cusp.
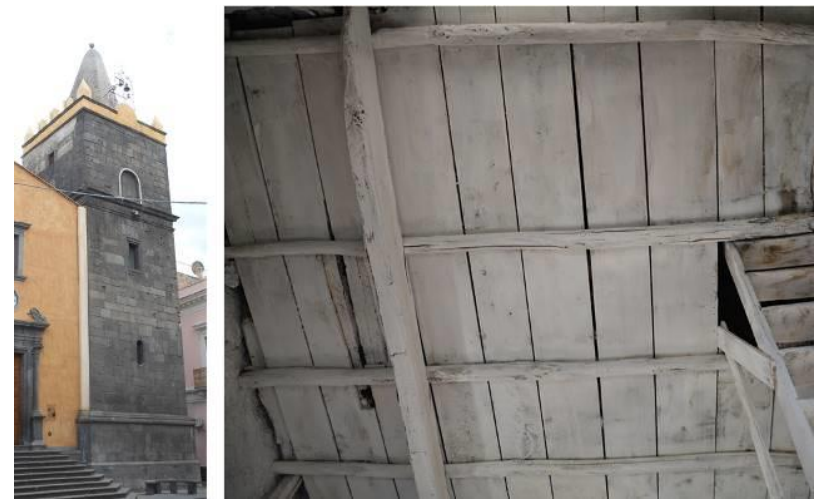

Figure 4. The bell tower of San Giovanni in Bronte (Ct). On the right, the floor under the cusp.
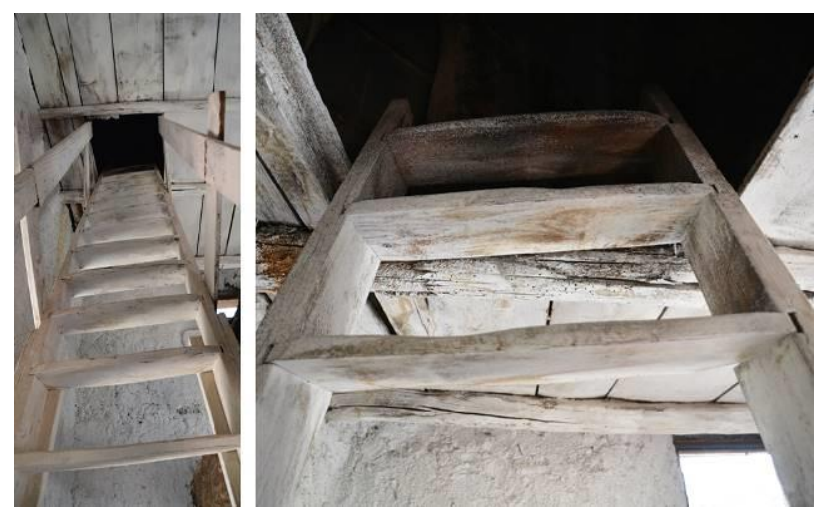

Figure 5. Stair in the bell cell of San Giovanni in Bronte $(\mathrm{Ct})$.

\subsection{Wooden stairs}

The vertical connection systems found in Etnean bell towers are generally a function of the geometric configuration of the interior spaces of the tower. The spiral stairs (like "Caracol de Mallorca" or "Caracol de husillo") in lava stone or limestone ashlars, inside some towers, denote the presence of a design by an expert architect (Bares, 2013); instead, in floors like those just described, we can find stair systems more rudimentary and more similar to the technological solutions of rural buildings.

In belfries with a small plan, between an intermediate floor and the other, were placed simple wooden ladders with pegs (today in iron) leaning against the beams of the wooden floors with strong inclinations. In the square-shaped bell towers, between one intermediate floor and the other, there were stairs with minor inclinations. These were generally made up of two lateral fir wood boards, called "cosciali", leaning against the beams of the floor, and treads made up of small boards embedded in special seats carved into the "cosciali" (De Felice et al., 2006). Such a construction system with treads embedded in the "cosciali", if made with enough connections and nails, allowed to obtain a fair resistance and rigidity with a minimum amount of timber (De Cesaris, 1996). In some cases, as in Sant'Agata al Borgo in Catania (Figure 1), the stair is placed next to a wall and the "cosciali" are arranged parallel to the beams of the floor; in other cases, the "cosciali" are arranged orthogonally to the beams and therefore assume a greater inclination, as in San Giovanni a Bronte (Figure 5). The balusters are made in a rudimentary way with uprights consisting of planks nailed to the "cosciali" and the handrail consisting of a board nailed to the uprights.

\subsection{Stairs on vaults}

In belfries without intermediate floors, the vertical connection systems are frequently solved by stairs with stairwell ("a pozzo"). These stairs are made with ramps and landings on arches and rampant vaults, borrowing from the lexicon of basic residential buildings.

The construction system of the rampant vaults, typical of the Etnea area, involves the use of minute and light volcanic stone material of regular size, arranged on a temporary wooden centering and solidified by a very fluid jet of gypsum mortar (Randazzo, 1988).

In the analysed specimens, such as the stairs of the bell tower of San Giuseppe in Aci Castello datable around 1742 (Figure 6), the thickness of this concrete shell is about $15 \mathrm{~cm}$. The steps of this type of stair are in pressed brick masonry, with treads in quadrangular slabs of calcarenite or terracotta.

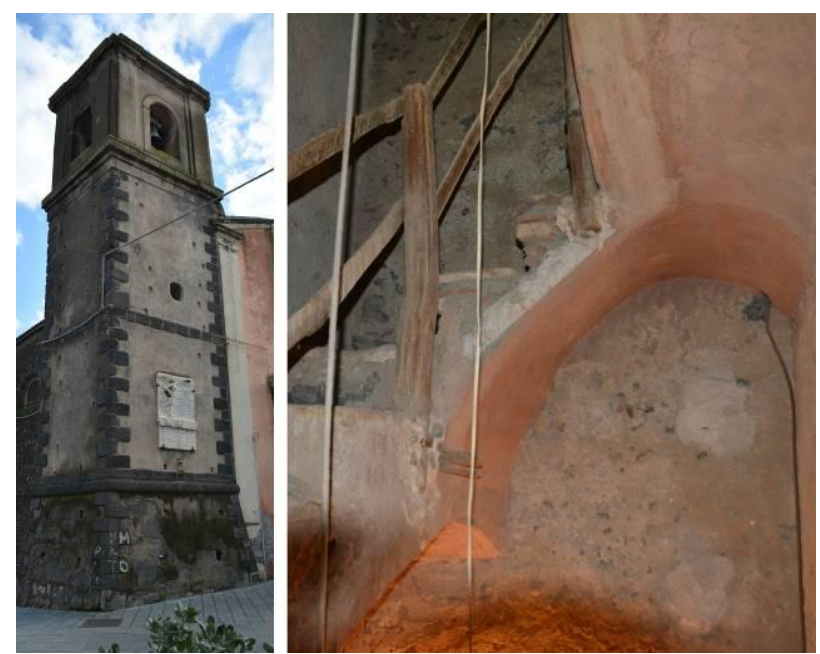

Figure 6. The bell tower of San Giuseppe in Aci Castello (Ct). Stairs on rampant vaults.

\section{REPLACEMENT INTERVENTIONS}

As is well known, the industrialization that affected the building process from the end of the nineteenth to the beginning of the twentieth century produced innovations in terms of basic materials and building techniques. Therefore, instead of repairing or mimetically replacing damaged building elements, the Etnean bell towers suffered considerable transformations. 


\subsection{Floors and stairs with NP iron beams}

The replacements (now "historical") often involved the intermediate wooden floors and stairs systems on rampant vaults. Until the first half of the twentieth century, in the Etna area, these components were often replaced by floors, ramps and landings with double-T iron beams (called "Normal Profile" or "NP"). These beams are arranged with variable spacing between $60 \mathrm{~cm}$ and $80 \mathrm{~cm}$. The filling, between one beam and the other, changes according to the age of construction. In the oldest cases, this was in pumice stone and gypsum mortar, in analogy to the building techniques of the vaults (Randazzo, 1988). We can find examples of this type in the ramps and landings of the towers of the Acireale Cathedral (about 1544) (Figure 7) or those of the bell cell in the church of San Filippo in Aci San Filippo (1559) (Figure 8). In more recent cases, the filling in pumice and gypsum mortar is replaced by brick panels, as we can see on the second floor of the tower of San Giovanni in Bronte. In this tower, the replacement intervention has not erased the memory of the original construction system, so the support beams of the previous wooden floor remain below the new structure (Figure 9). In the case of the flights of stairs made with this technique, the steps are in concrete.
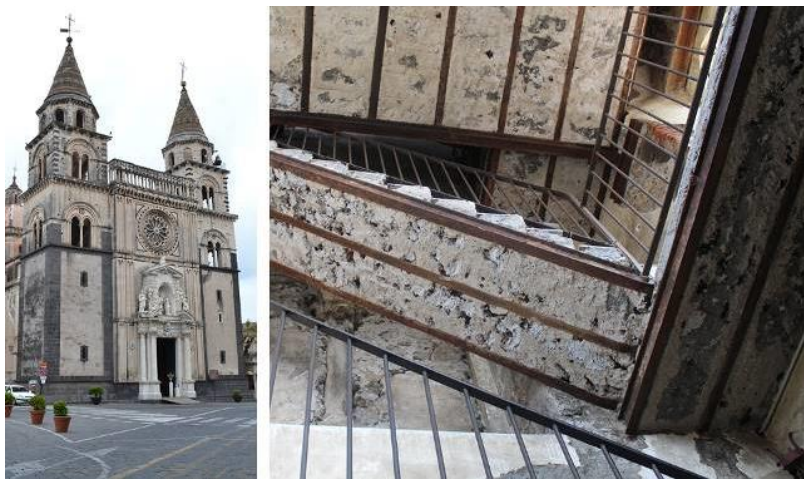

Figure 7. The bell towers of the Cathedral of Acireale $(\mathrm{Ct})$. Floors, stairs and landings with NP iron beams.
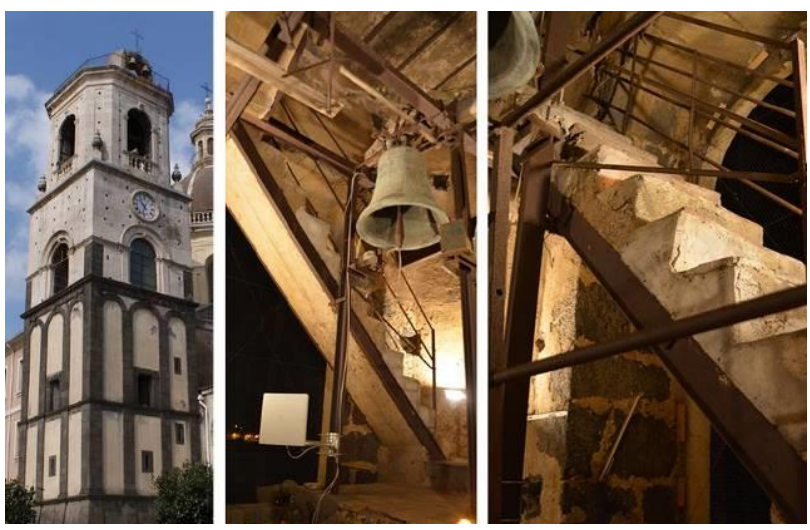

Figure 8. The bell tower of San Filippo in Aci San Filippo (Aci Catena - Ct). Stairs with NP iron beams.

\subsection{Iron stairs}

Where wooden floors have been replaced with iron beam systems, wooden stairs have also been replaced with similar iron ones. In some cases, the emptying of the tower involved the installation of an iron spiral stair, like in the belfry of the SS. Crocifisso di Majorana in Catania. (Figure 10).
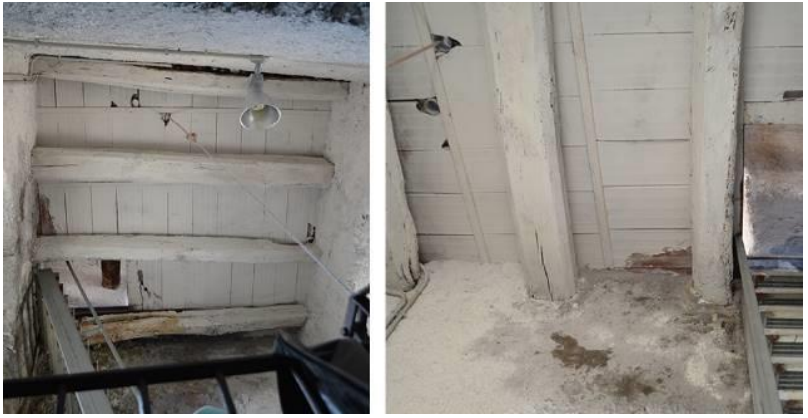

Figure 9. Intermediate floor in the bell tower of San Giovanni in Bronte $(\mathrm{Ct})$.

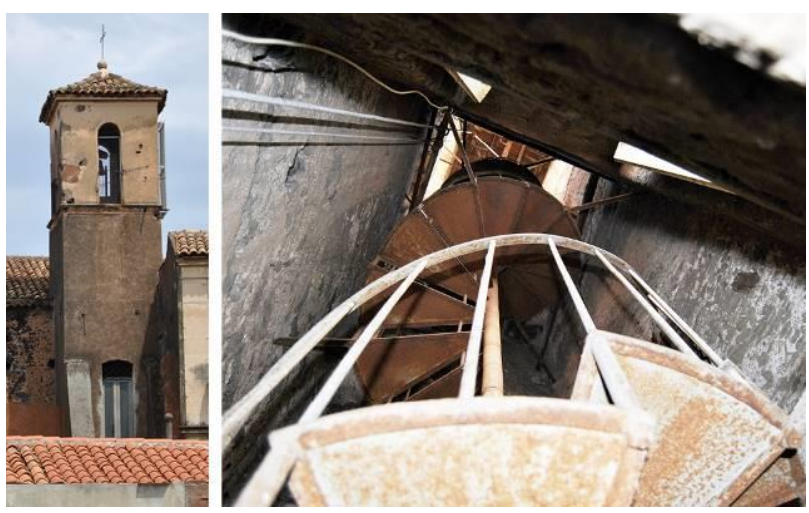

Figure 10. The bell tower of the SS. Crocifisso di Majorana in Catania. Iron spiral staircase.

\subsection{The reinforced concrete replacements}

The analysis of some emblematic cases for the considered area and the related historical and archival investigations have also provided a clear view of the "extreme" results of the replacement works of traditional technologies.

The belfry of the SS. Trinità church in Bronte was built in subsequent stages starting from 1579. The sixteenth century pastoral visits date the start of the construction of the internal staircase systems from 1598 (Mandalà, 1997). The tower follows many dictates of the C. Borromeo "Instructions" for the new churches (Della Torre et al., 2000). About $30 \mathrm{~m}$ high and with a quadrangular plan of about $13 \mathrm{~m}^{2}$, the bell tower is leaning against the main nave and has a pavilion vault on the first level; a high pyramidal cusp crowns the top of the fifth level. Some pictures dating back to 1966 , preserved in the Archive of the Superintendence of Cultural Heritage of Catania, allow us to formulate some hypotheses on how the interior of the tower could have looked before the interventions that transformed it between the 70s and $90 \mathrm{~s}$ of the twentieth century. Despite the narrow field of view of the examined frames, which does not allow a complete understanding of the complex wooden structures, a first hypothesis that we can formulate would indicate the intermediate levels of the bell tower characterized by rudimentary floors with twin main beams.

These beams were roughly hewn and supported the upper planking. Under these, additional auxiliary beams were placed next to the stair and placed orthogonally to the main beams of the floor. 

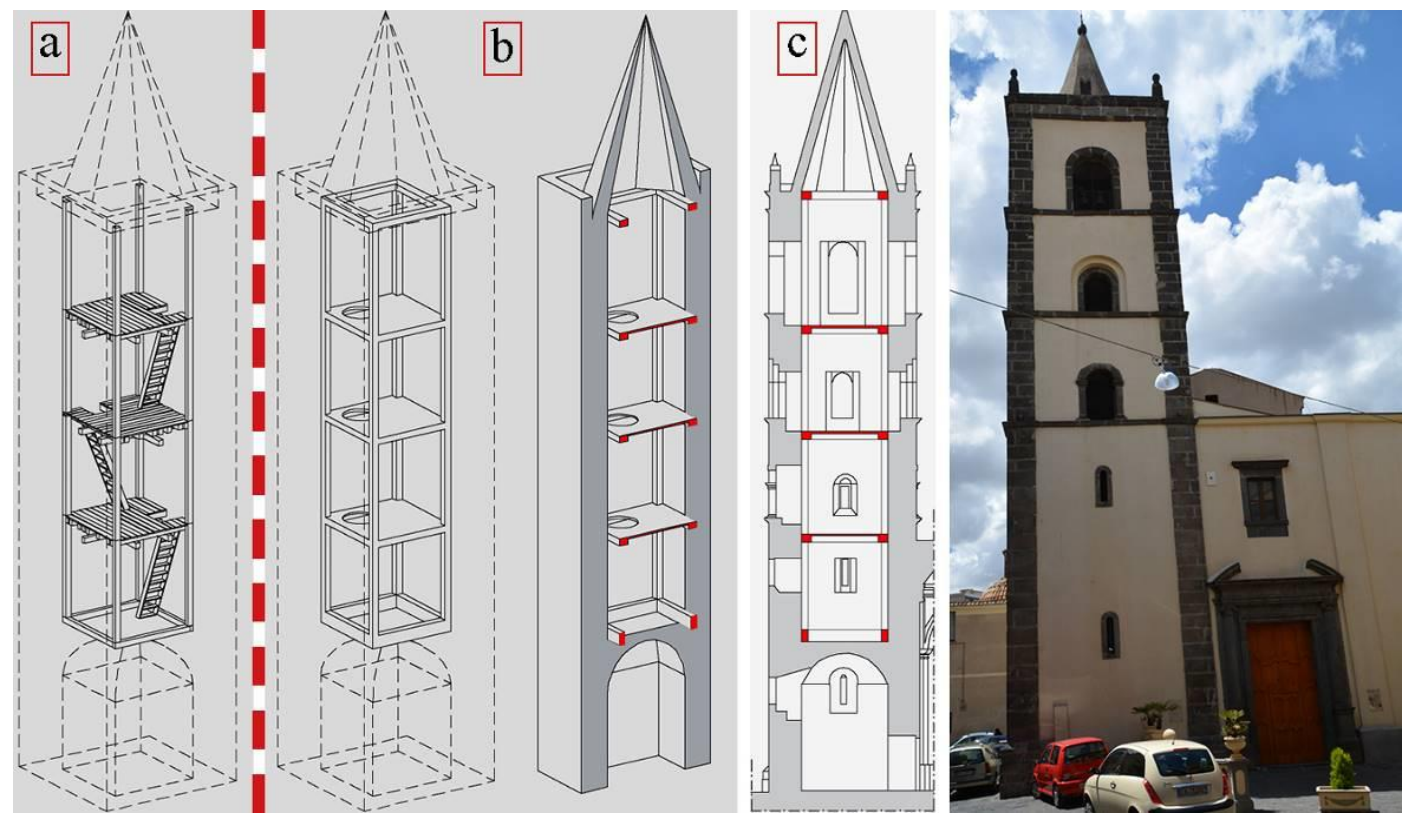

Figure 11. The bell tower of SS. Trinità in Bronte (Ct): a) 3D scheme of one of the hypotheses on the original wooden structure. b) Overall dimensions of the reinforced concrete structure inside the tower: three-dimensional scheme. c) Cross-section of the tower: in red, the reinforced concrete structure.

As already mentioned for other buildings, these reinforcing beams may have been added later, since their location near the archivolts of the windows indicates an incongruous arrangement for the organisation of the masonry and weaving of the original floor (De Felice et al., 2006) (Figure 11). The stairs were either wooden ladders with pegs or ramps with "cosciali".

Instead of the described floors, another hypothesis (not very usual in this area) could suggest a system of wooden stairs and balconies, leaning against the internal perimeter of the tower and consisting of cantilevered wooden floors supported by several auxiliary beams.

In both hypotheses, moreover, it is certain that at the inner corners of the bell tower there were four wooden columns, for the whole height of the tower and resting above the pavilion vault on the ground floor (perhaps above a wooden curb). These columns, fixed to the walls with specific iron brackets, supported the wooden structures on which the bells were hung on the last level. At the end of the 60 s of the twentieth century, the parish priest reported to the Superintendence evident vertical cracks on the façades. These cracks connected the windows of each level of the tower and were the evident trace of an incipient damage mechanism by vertical subdivision in the absence of effective chaining of the perimeter walls.

The consolidation works (carried out following this report) led to the complete demolition of the wooden structure and the construction of a reinforced concrete framed system (perhaps thought of as a hypothetical re-proposition in reinforced concrete of the previous wooden structure).

The new construction is characterized by beams $(27 \times 40 \mathrm{~cm})$, pillars $(27 \times 27 \mathrm{~cm})$ and thin reinforced concrete plate slab $(8 \mathrm{~cm}$ thick) (Figure 12). This frame is characterized by a lower curb (with a cross-section of $27 \times 52 \mathrm{~cm}$ ), which rests above the vault of the ground floor; at the upper end, the frame supports the steel beams on which the large bells are now hung. The spiral staircases installed are made of steel. (Figure 13).
A further intervention of substitution or real "gutting" of the inner structure of the towers can be found in another belfry of Bronte, that of the church of Santa Maria della Catena (first half of seventeenth century).
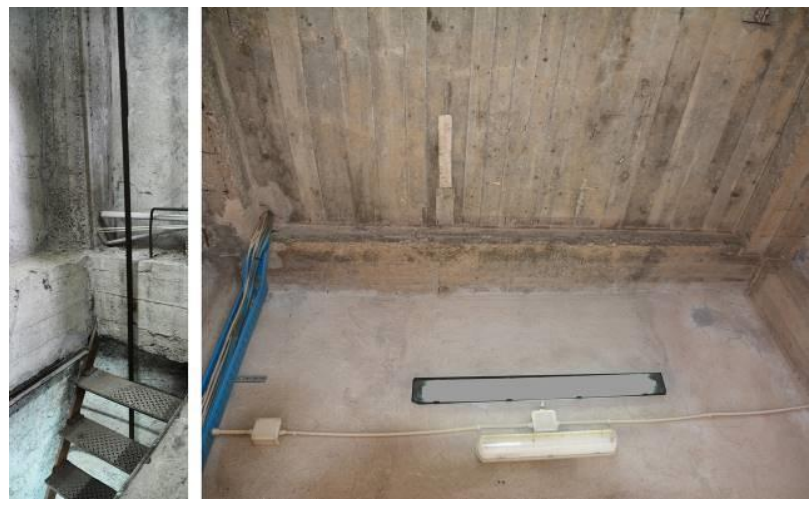

Figure 12. The new reinforced concrete structure in the bell tower of SS. Trinità in Bronte $(\mathrm{Ct})$.
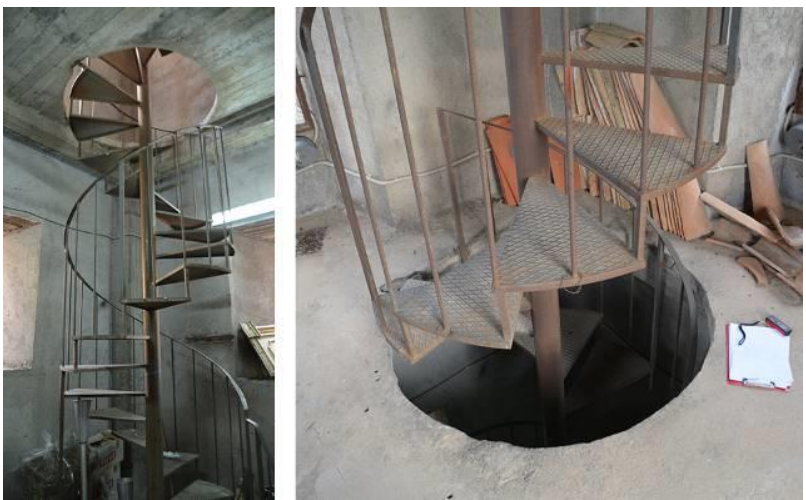

Figure 13. The steel spiral staircase in the bell tower of SS. Trinità in Bronte $(\mathrm{Ct})$. 

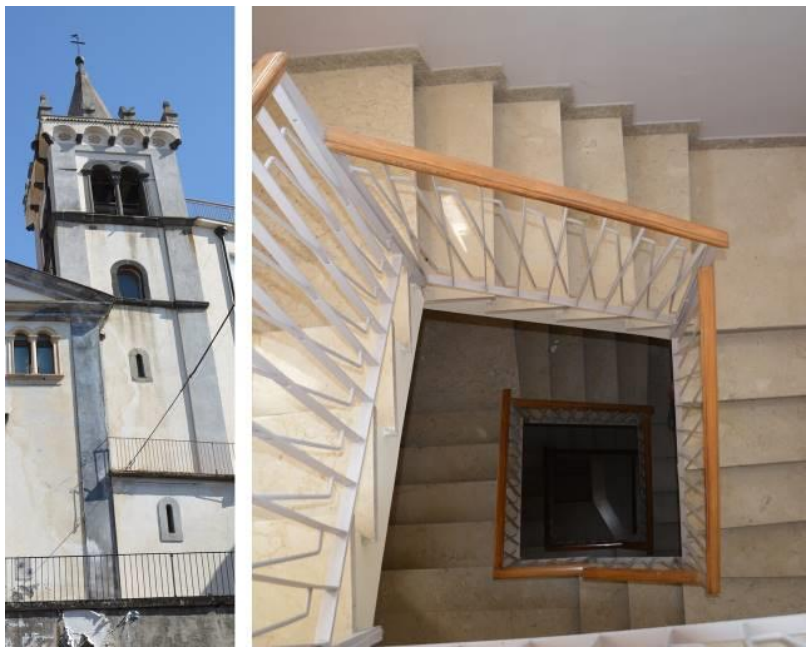

Figure 14. The bell tower of Santa Maria della Catena in Bronte $(\mathrm{Ct})$. Inner staircase.

Although we have not found the documentation during the archival investigation and we cannot know what the internal space originally looked like, it is evident that a replacement work with a system of reinforced concrete stairs has been carried out (Figure 14). This structure does not lead to the bell cell but is used as a service staircase for the school buildings built in adherence to the tower, in the second half of the twentieth century.

\section{CONCLUSIONS}

The documentation and knowledge of the building elements inside the bell towers can be essential both from a cultural point of view and from their survival, thanks to the possibility of organizing planned maintenance works, even before any damage occurs. Despite the testimonial value of these elements inside the monumental Etnean bell towers, the paper highlights how poorly reasoned transformation interventions can erase part of this pre-modern building heritage.

Indeed, the bell towers have always been considered a service room of the adjacent church: a place often neglected and without maintenance.

In addition to the cultural relevance of the traditional techniques borrowed from vernacular architecture, it must also be highlighted that the replacements often hide a lack of willingness of the designers to understand the building on which they are called to operate.

Moreover, the emblematic gutting interventions carried out in the Bronte bell towers are the result of an era in which the designers were trained in the extreme trust in reinforced concrete. In the name of such trust and safety, also pretentiously invocating the 1931 Athens Charter for the Restoration and the 1964 Venice Charter for the Conservation and Restoration of Monuments and Sites, the consolidation actions sacrificed cultural and conservation issues. The trend to limit heavy consolidation works, which modelled ancient buildings according to the static scheme of modern materials, began to spread only in 1986 with the Raccomandazioni per gli interventi sul patrimonio monumentale a tipologia specialistica in zone sismiche.
Already in 1984, as part of the debate about the relationship between restoration and the use of concrete, A. Giuffrè implored «mercy for the monuments», inviting the designers to know how to read and recognize the history of the monument (with its different materials, construction phases) before working on it.

Only by fully understanding the structural and material "language" of the building, we can establish a dialogic relationship with them, leading to minimal, respectful (but always recognizable) restoration and consolidation interventions. The words of A. Giuffrè perfectly adhere to the case considered here:

The wooden floors of a seventeenth century building, ruined by age, cannot be brutally replaced by rigid modern floors, however solid and efficient they may be. The relationship between wood and wall was part of the language of the building; (...) there must be a reasonable motivation to modify this static scheme and replace a directional warp with a homogeneous plate slab (Giuffrè, 1984).

The high reinforced concrete structure (without a real foundation) of the SS. Trinità bell tower in Bronte shows dynamic behaviour that is different from the masonry structures to which it is leaning. In the event of an earthquake, the two adjacent structures could resonate, oscillating independently of each other and triggering a dangerous interpenetration of the concrete frame in the masonry.

The studies on the effects of earthquakes that have hit Italy in the last twenty years and the 2011 Italian "Guidelines for the assessment and reduction of seismic risk of cultural heritage" have once again confirmed the key importance of a specific and preventive path of knowledge on the monument.

This knowledge should involve the analysis of the geometrical and constructive aspects, the instrumental detection of structural damages, the historical-archival investigation of different building phases, traumatic events and any previous restorations. All this in order to have an idea, even quantitative, of the structural behaviour in the short and long term (Coïsson, 2019).

From this point of view, the interventions on the inner structures of the SS. Trinità bell tower in Bronte can be considered a lost opportunity for the implementation of safety and protection measures for the ancient wooden structures with minimal interventions, aimed at bringing the construction systems of the floors and walls back to the "good rule of the Art".

\section{ACKNOWLEDGEMENTS}

This work was conducted jointly; however, for editorial reasons, paragraphs 1,3 and 6 were edited by A. Mondello and A. Salemi; paragraphs 2, 4, 5 were edited by A. Mondello.

In Figures 1-2-3, the photos on the right are taken from ICR Risk Map of Cultural Heritage.

The photos in Figure 7 were taken by the students of the Architectural Restoration course (Degree in Architecture and Building Engineering) - University of Catania, A.A. 20192020: S. Bonaccorsi, C. Finocchiaro, G. Sciacca, L. Spadafora. The photos in Figure 10 were taken by Eng. F. Anastasi. All the other figures are authors' elaborations. 
The authors thank all the people in charge for the consulted archives and the surveyed buildings.

This work has been partially financed by the University of Catania within the project "Piano della Ricerca Dipartimentale 2016-2018" (COREC project) of the DICAR - Department of Civil Engineering and Architecture.

\section{REFERENCES}

Aymerich, C., Dell'Acqua, A. C., Fatta, G., Pastore, P., Tagliaventi, G., Zordan, L. (Eds.), 2007. Architettura di base. Alinea Editrice, Firenze.

Barbera, S., 1998. Recuperare Catania. Studi per il riuso di ventuno complessi architettonici del centro storico. Gangemi Editore, Roma.

Bares, M. M., 2013. Le scale elicoidali con vuoto centrale: tradizioni costruttive del Val di Noto nel Settecento. In: Antista, G., Bares, M. M., (Eds.), Le scale in pietra a vista nel Mediterraneo. Edizioni Caracol, Palermo, pp. 73-92.

Blasi, C. (Ed.), 2013. Architettura storica e terremoti. Protocolli operativi per la conoscenza e la tutela. Wolters Kluwer Italia, Milanofiori Assago.

Coïsson, E., 2019. Riduzione del rischio sismico degli edifici storici in muratura. Maggioli Editore, Santarcangelo di Romagnia.

De Cesaris, F., 1996. Gli elementi costruttivi tradizionali. I collegamenti verticali. In: Carbonara, G. (Ed.), Trattato di restauro architettonico. Utet, Torino, vol. II, pp. 177-192.

De Felice, G., Pugliano, A., 2006. Il lessico costruttivo dell'edilizia storica. In Giuffrè, A. (Ed.), Sicurezza e conservazione dei centri storici: il caso Ortigia. Codice di pratica per gli interventi antisismici nel centro storico. Editori Laterza, Roma, pp. 69-99.

Della Torre, S., Marinelli, M., Adorni, F. (Eds.), 2000. Instructionum fabricae et supellectilis ecclesiasticae: Libri II Caroli Borromei (1577). Libreria Editrice Vaticana - Axios Group, Città del Vaticano.

Dezzi Bardeschi, M., Ientile, R., Devoti, C., Sammartano, G., Spanò, A., Naretto, M., Lupo, F., 2017. Architetture verticali e vulnerabilità sismica. Torri e campanili in Piemonte. Altralinea Edizioni s.r.l., Firenze.

Direttiva del Presidente del Consiglio dei Ministri 09 febbraio 2011 (Supplemento Ordinario n. 54 della G.U. 47 del 26/02/2011), Linee Guida per la valutazione e riduzione del rischio sismico del patrimonio culturale con riferimento alle Norme tecniche per le costruzioni di cui al decreto del Ministero delle infrastrutture e dei trasporti del 14 gennaio 2008.

Doglioni, F., Moretti, A., Petrini, V., 1994. Le chiese e il terremoto. Dalla vulnerabilità constatata nel terremoto del Friuli al miglioramento antisismico nel restauro, verso una politica di prevenzione. Edizioni LINT, Trieste.

Fichera, F., 1893. Tariffa dei lavori di costruzione per la città di Catania. Giannotta Ed., Catania.
García González, E., 2015. Campanarios del siglo XVIII en el Bajo Segura. Construcción y geometría. $\mathrm{PhD}$ Thesis in Edificación, Tecnología, Investigatión y Desarollo. Universidad de Alicante, Director: Pablo Martí Ciriquián.

Giuffrè, A., 1984. Pietà per i monumenti. In Carbonara, G. (Ed.), Restauro e cemento in architettura. Associazione italiana tecnico economica del cemento, Roma, vol. 2, pp. 120-122.

Italian Central Institute for Restoration, 2009. Risk Map of Cultural Heritage.

Lionello, A., 2013. Tecniche costruttive, dissesti e consolidamenti dei campanili di Venezia. Corbo e Fiore, Venezia.

Mandalà, G., 1997. Il vescovo e la chiesa locale: vita liturgica e pastorale a Bronte nelle visite dei due Torres (1574-1598) arcivescovi di Monreale. Salvatore Sciascia Editore, Caltanissetta - Roma.

Mondello, A., 2019. Torri campanarie degli edifici ecclesiastici tradizionali allo specchio tra conoscenza e sicurezza. Tecnologia e forma negli areali a rischio della Sicilia orientale $e$ della Castilla y León. $\mathrm{PhD}$ Thesis in Evaluation and mitigation of urban and land risks, XXXI cycle, University of Catania, Supervisor Prof. Angelo Salemi.

Mondello, A., Garozzo, R., Salemi, A., Santagati, C., 2019. Hbim for the seismic vulnerability assessment of traditional bell towers. Int. Arch. Photogramm. Remote Sens. Spatial Inf. Sci., XLII-2/W15, 791-798, doi.org/10.5194/isprs-archives-XLII-2W15-791-2019.

Randazzo, G., 1988. Le strutture murarie negli edifici del centro storico di Catania. In: Margani, L., Salemi, A. (Eds.), Materiali e tecniche costruttive della tradizione siciliana. Tre studi su Catania. Documenti dell'Istituto Dipartimentale di Architettura e Urbanistica dell'Università di Catania, Catania, n. 16, pp. 109143 .

Salemi, A., 2018. Le cortine del centro storico di Catania. Materiali, forma e immagine urbana. Edizioni Efesto, Roma.

Sánchez Rivera, J. I., San José Alonso, J. I., Fernández Martín, J. J., 2014. Ocho torres: análisis sobre la evolución de campanarios del siglo XVI en la provincia de Burgos. Ediciones Universidad de Valladolid, Valladolid. 